Rozprawy Komisji Językowej ŁTN, t. LXVI, 2018

ISSN 0076-0390; e-ISSN 2450-9310

https://doi.org/10.26485/RKJ/2018/66/8

Adam Fałowski*

Anna Budziak**

\title{
SŁOWNICTWO UKRAIŃSKIE ZE ZBIORÓW IWANA WAHYLEWYCZA (2)
}

\author{
UKRAINIAN VOCABULARY FROM \\ IVAN VAHYLEVYCH'S COLLECTION (2)
}

This article is a continuation of the research dealing with rare lexis found in the manuscript dictionaries by Ivan Vahylevych. The article is devoted to words beginning with W.

Keywords: Ukrainian lexicography, Ukrainian dialectology, etymology, loanwords, Ivan Vahylevych

Słowa kluczowe: leksykografia ukraińska, dialektologia ukraińska, etymologia, zapożyczenia, Iwan Wahylewycz

W 2014 roku, jako ósmy tom serii Studia Ruthenica Cracoviensia, ukazała się książka krakowskiej ukrainistki Anny Budziak, w której dokonano syntezy i opracowania leksykograficznego dorobku Iwana Wahylewycza (1811-1866), postaci bardzo zasłużonej dla ukraińskiej nauki i kultury. Książka nosi tytuł Rękopiśmienna spuścizna słownikarska Iwana Wahylewycza. Jak pisze autorka w Stowie wstęnym:

W niniejszym opracowaniu podjęto próbę ukazania całości dorobku słownikarskiego I. Wahylewycza i przedstawiono jego rękopiśmienne słowniki zawierające materiał ukraiński [Budziak, 2014, s. 5].

* Katedra Ukrainistyki, Instytut Filologii Wschodniosłowiańskiej, Wydział Filologiczny Uniwersytetu Jagiellońskiego, ul. Romana Ingardena 3, 30-060 Kraków; e-mail: adam.falowski@ uj.edu.pl.

** Katedra Ukrainistyki, Instytut Filologii Wschodniosłowiańskiej, Wydział Filologiczny Uniwersytetu Jagiellońskiego, ul. Romana Ingardena 3, 30-060 Kraków; anna.budziak@uj.edu.pl. 


\section{Dalej autorka stwierdza:}

Zasadniczą część niniejszej publikacji stanowi słownik zawierający uporządkowany materiał zebrany w trzech najważniejszych rękopiśmiennych rejestrach autorstwa I. Wahylewycza. Zostały tu wykorzystane dwa rękopisy przechowywane w archiwach Biblioteki Naukowej im. W. Stefanyka we Lwowie i Biblioteki Rosyjskiej Akademii Nauk w Petersburgu - warianty słownika ukraińsko-niemiecko-łacińskiego zwanego Idyotykonem oraz rękopis słownika ukraińsko-polsko-niemiecko-łacińskiego (Słownik języka południowo-ruskiego), który również trafił do ostatniej z wymienionych bibliotek [Budziak, 2014, s. 6-7].

Nie wiadomo dokładnie, ile jednostek leksykalnych liczy słownik zajmujący strony 113-410 przywoływanej książki. Przybliżone obrachunki pozwalają przypuszczać, że chodzi o jakieś 15 tysięcy jednostek. Jest to słownictwo niezwykle interesujące, w wielu wypadkach rzadkie, dialektalne, niekiedy archaiczne, wydobyte z zabytków staroruskich (gramoty, latopisy). Wymaga ono z pewnością głębszej refleksji językoznawczej.

Dokonawszy konfrontacji całości zaprezentowanego materiału leksykograficznego zgromadzonego przez I. Wahylewycza ze Stownikiem etymologicznym języka ukraińskiego [ESUM, 1982-], udało się wyodrębnić kilkaset (około 700) wyrazów, które ESUM pomija zupełnie, a jeśli je nawet uwzględnia, to z jakiegoś powodu (etymologia, semantyka, geografia) wymagają one szerszego komentarza leksykologicznego. Trudno przejść obojętnie wobec takiego bogactwa leksyki języka ukraińskiego, stąd też pomysł, aby w serii publikacji postarać się to osobliwe i rzadkie słownictwo przybliżyć szerszej społeczności badaczy i miłośników języka ukraińskiego. Niniejszy artykuł jest kontynuacją cyklu artykułów, który został zapoczątkowany w czasopiśmie „Studia Ucrainica Varsoviensia” [Fałowski, Budziak, 2018, s. 45-59], i zawiera omówienie haseł na literę W (postaci hasłowe omawianych wyrazów zostały wiernie przytoczone za publikacją A. Budziak).

вабити - hindern; impedire. IL, IP ${ }^{1}$

Homonimiczne wobec вабити - wabić; locken; allicere. SJPR²; locken. IP, które wszakże zostało odnotowane z innym akcentem, bo na środkowej sylabie, podczas gdy pierwsze na początkowej.

Prawdopodobnie postać ta jest efektem metatezy бавити 'забавляти, розважати, затримувати, затримуватись, перебувати', podobnie jak brus. вабіuь 'марнаваць час; забаўляць', вабіица 'затрымлівацца; забаўляцца, гуляць' [ESBM I, s. 10].

1 Skrót IL wprowadzony w książce A. Budziak oznacza, że hasło było odnotowane w wariancie lwowskim Idyotykonu, IP - w wariancie petersburskim.

2 Skrót SJPR oznacza, że źródłem jest Słownik języka południowo-ruskiego. 
вабша (huc.) - Morast; palus. IL, IP

Niejasne. Brak jakichkolwiek śladów tego terminu w monografii Mariana Jurkowskiego, poświęconej ukraińskiej terminologii hydrograficznej [Jurkowski, 1971].

Można z dużym ryzykiem przyjąć, że jest to derywat z sufiksem -ma od odnotowanego przez Iwana Werchratskiego w gwarach zakarpackich wyrazu вana 'місце, де стоїть вода; грузьке місце', о prasłowiańskich, a nawet praindoeuropejskich korzeniach (pie. *uep- '(stojąca) woda, mokradło' [ESUM I, s. 329; Boryś, 2008, s. 677], por.: strus. вапа 'мелкий залив, водоем со стоящей водой' [SRJ II, s. 16]; scs. vapa 'Sumpf, Teich, Gehölz' [Sadnik, Aitzetmüller, 1989, s. 148]. Nie da się też ostatecznie wykluczyć zależności od rum. ápă 'woda', apşoáră zdr. 'woda' [WSRP, s. 46, 49].

валочный - tauglich; aptus. IL, IP

Przymiotnik dobrze znany gwarom łemkowskim, bojkowskim i huculskim, por.: валушный 'tauglich, nützlich', тото не валушне 'dies taugt nicht' [Верхратський, 1902, s. 395]; валушний 'użyteczny' [Горощак, 2004, s. 29]; валочний 1. '(про свідків) важливий’; 2. '(про документи) дійсний' [Онишкевич, 1984, I, s. 82]; wałocznyj/wałowcznyj 'odpowiedni, godny, zdolny' [Janów, 2001, s. 252]. ESUM [I, s. 326] przytacza dial. валовщний 'приналежний', daw. валовшньй, валушный 'тс.; гідний’ (XVI-XVII ст.). Występuje także w gwarach słowackich, np. valušny 'súci, schopný, zpusobilý' [Kálal, Kálal, 1923, s. 759], valušni 'súci, vhodný' [Buffa, 2004, s. 296].

Źródeł wyrazu należy szukać w języku węgierskim, por.: węg. való 'prawdziwy, rzeczywisty; godny, odpowiedni, stosowny', valós 'rzeczywisty, stosowny'.

валочный - gewisz; certus (IP $2^{3}$ ). IL, IP

Zapewne wariant semantyczny poprzedniego.

варвъ $+{ }^{4}$ (IP) - (wiarus); Kriegsmann; miles. IL, IP

Por.: SRJ [II, s. 17]: варвъ 'язычник, нехристиянин (?)' (Ипат. лет. 1251), z odesłaniem do варваръ, варваринъ.

варкій (huc.) $)^{5}$ - gefährlich (IL, IP), schwachlich (IP); anceps. IL, IP Por.: варівний 'небезпечний', 'якого треба остерігатися' [Онишкевич, 1984, I, s. 84]; wariwko 'ostrożnie (?)', wariwnyj 'straszny', warko 'niebezpiecznie, strasznie', warkiszczyj, warkyj 'ciężki, niebezpieczny, niepewny’ [Janów, 2001,

3 Cyfra przy skrócie wskazującym słownik informuje, że wyraz hasłowy był odnotowany powtórnie w dopiskach i tam pojawiła się oznaczona nim forma.

${ }^{4}$ Kwalifikator + pochodzi od I. Wahylewycza i wskazuje na słownictwo dawne.

5 Kwalifikator huc. pochodzi od I. Wahylewycza i oznacza słownictwo huculskie. 
s. 252]; варівкий // варівний // варкий 1. 'небезпечний, страшний'; 2. 'схильний до хвороб' [HН, s. 33].

ESUM [I, s. 334] widzi tu starą pożyczkę niemiecka, por.: „[варувати] 'зберігати, берегти, остерігати' [...], [варівкий] 'нерішучий; небезпечний', [варівний] 'тс.', [варувкий] 'соромливий', [варівко] 'небезпечно; незручно', [варівно] 'тс.', [варко] 'небезпечно'[...]; - очевидно, спільнослов'янське запозичення з давньоверхньонімецької мови (двн. (bi)warōn 'зберігати, берегти', нвн. wáhren 'тс.')".

Większość znaczeń odnotowanych w ESUM nie ma jednak związku z chronieniem, obrona, por:: pol. warowny 'umocniony, zabezpieczony przed wrogami, obronny'. Wydaje się, że można tu raczej wysunąć hipotezę o pokrewieństwie z ps. *varzkъ(jb) i stsł. ВАРЬАИВТ ' powściagliwy, chętny do zrobienia czegoś, nieposkromiony, okrutny, zaciekły, gwałtowny; namiętny') [Черниш, 2003, s. 300]. Por.: pol. przest. wrzeć na kogo, przeciw komu 'gniewać się, złościć się na kogo, występować przeciw komu gwa1townie' [Doroszewski, 1958-1969, s.v.]; kipieć gniewem 'o silnym wzburzeniu'; gotować się 'przen. kłębić się, kotłować się' [Doroszewski, 1958-1969, s.v.]. Drugie z podanych przez Wahylewycza znaczeń ('chorowity'), potwierdzone w słowniku gwar huculskich, również może sprowadzać się do tego gniazda na podstawie skojarzenia 'taki, który często gorączkuje'; por.: ros. варкие дрова 'które dają dużo żaru' [Черниш, 2003, s. 299].

вервещебди - wierzch drzew; die Wipfel; $\mathrm{xxx}^{6}$. SJPR

Niejasne. Druga część wyrazu zdradza pewne podobieństwo do ukr. dial. щзоб 'стрімка вершина гори, бескид; вершина гори; верховіття, вершок дерева', щоб 'вершина гори, вершок дерева', щовба, щолба 'вершина гори, бескид', co zapewne wywodzi się z ps. dial. *sčblbъ $\left(<*^{*} s k b l b ъ\right)$, por.: pie. *skel- 'бити, колоти' [ESUM VI, s. 513].

вервинс - wrzawa; Wirrwar. SJPR

Por.: warwodyty 'strzelać', 'hałasować (?)', warwid: warwyd 'harmider, wrzawa, zgiełk' [Janów, 2001, s. 252]; варводити 'гавкати' [Горбач, 1979, s. 331].

Według ESUM [I, s. 331]: „,[варводити] 'здіймати метушню, створювати безладдя, плутанину' Ж, [варвідувати] 'шуміти, робити розгардіаш Ж, Я; ревіти Ж; стріляти ЕЗб 26', [варвідня] 'розгардіаш, сум'яття' Я; - не зовсім ясне утворення, можливо, пов’язані з [гарведа] 'сварка', яке могло зазнати

\footnotetext{
${ }^{6}$ Fragment rękopisu jest nieczytelny.
} 
впливу слова варивода 'вередлива людина, що змучує інших своїми причіпками', яке складається з основ дієслова варити та іменника вода".

вервь +- Gau; districtus. IL, IP

Por.: „вервь II. только др.-русск. вервь (из *вьрвь?) 'община'; [...]. Более приемлемо объяснение Карского (РП 93), который отождествляет др.-русск. слово с вервь I 'веревка', исходя при этом из знач. 'участок земли, отмеренный веревкой”' [Фасмер, 1986-1987, I, s. 294], takie wyjaśnienie podtrzymuje też Aleksandr Anikin [Аникин, 2012, s. 269].

веревня (pod.) - Hohlweg; fauces. IL, IP

Raczej nie chodzi tu о варовня 'сторожевая башня' [Грінченко, 1996-1997, I, s. 127], pol. warownia 'twierdza, forteca', ani też brus. вароўня 'цёплы свіран, куды ставяць на зіму капусту, бульбу і інш.', a także dial. вараўня (варыўня) 'пограб, яма, у якой хаваюць бульбу' [ESBM II, s. 64] głównie z powodów semantycznych.

Być może należy się doszukiwać związku z bojkowskim ворованя 'калюжа' [Онишкевич, 1984, I, s. 144], wyrowynja 'wir, odmęt, otchłań; głębokie miejsce w wodzie z wirami; lej wiru', co należy wiązać z wyr 'wir' [Jurkowski, 1971, s. 93, 101].

верзь - przepaść; Abgrund; barathrum. SJPR; Luft; chasma. IL, IP Potwierdzone jedynie przez Jakowa Hołowackiego [Головацький, 1982, s. 394]: верзь (стрый.) 'бездна, пропасть'.

Należy dopatrywać się związku z ps. *vbrgati 'rzucać, ciskać', ukr. верzamu 'rzucać z siła, ciskać', ros. низвергать 'zrzucać, strącać' oraz ukr. верж 'miejsce, gdzie się wyrzuca, zrzuca' 7 .

верстати*8 - treten; calcare. IL, IP

Por.: верстати - дорогу, путь 'держать путь' [Грінченко, 1996-1997, I, s. 138]; верстати шлях, дорогу, путь і т.ін. 'пересуватися в певному напрямку, йти кудись' [WTSSUM, s. 83]. Semantycznie nawiązuje wyraźnie do ros. верстать ‘равнять, выравнивать' [Фасмер, 1986-1987, I, s. 300; Шанский, 1963-, I/3, s. 64; ESBM II, s. 309].

Według ESUM [I, s. 357]: „верства 'міра довжини; прошарок', верста [версть] 'верста' Ж, [...], верстати (полігр. і 'прямувати, простувати'),

7 Dziękujemy za podpowiedź Aleksandrowi Iliadi z Instytutu Językoznawstwa UAN w Kijowie.

8 Kwalifikator * pochodzi od I. Wahylewycza i oznacza słownictwo dialektalne. 
верствувати, переверстка, ст. верста (XV-XVII ст.), верства (XVII ст.)". Owoc dziedzictwa prasłowiańskiego i praindoeuropejskiego.

верчь* - eche Art Hochzeitsbrot. IL, IP

Etymologicznie powiązane z czasownikiem вертіти, por.: ,,вертіти [...], [верч] 'віхоть, пучок; згорток кори для постола Л; невелика булка, яку давали старості на весіллі', верчик '[...] плетена булка'” [ESUM I, s. 358-60]. Por. także brus. dial. верч, верчык, m.in. 'пшанічны хлеб, па-асобаму выпечаны і аздоблены, каравай’, верчык ‘баранак’, pochodzące z ps. *vbrt-jb < *vbrtěti [ESBM II; 89].

ветити - przechodzić w liczbie; an Zahl über steigen. SJPR; übersteigen; transcedere. IL, IP

Znane gwarom huculskim, por.: wetyty 'przewyższać', także perewetyty, powetyty [Janów, 2001, s. 256]; ветити 'рідк. перевершувати (у чому), бути кращим (від кого)' [HН, s. 35].

ESUM [I, s. 366] wiąże dial. ветити 'перевершувати, переважати, перевищувати; верховодити' z [вети] 'відплата', [ветувати] 'віддячувати, відплачувати', pochodzącymi z pol. wety ‘винагорода судді після суду; десерт’, wetować ‘відплачувати тією ж монетою' [tamże].

вздриглЊнс - czułość; ein zartes Gefühl. SJPR; вздриглЊнье (boj.) ${ }^{9}$ - (litość) (IP); Mitgefühl; commiseratio. IL, IP

Mychajło Onyszkewycz [Онишкевич, 1984, I, s. 95] powtarza za I. Wahylewyczem: „,здриглінє [Ваг. 53] „сіt” (? - Ред.)”.

Niewatpliwie nawiązuje do дрижати, ps. *drъžati, *drъgati, por.: „дрижати [...], здригатися, [здрігатися], [здріжсатися] 'затремтіти' Ж, [здрогнутися Ж, здриг, здриги, здригливий Я]” [ESUM II, s. 127].

Typowe dla abstraktów przekształcenie semantyczne: stan fizyczny $>$ stan psychiczny, czyli 'drżenie ciała' > 'czułość, litość, współczucie'.

Nieco inny rozwój znaczeniowy obserwujemy w przypadku stukr. вздрыгательно 'боязко, лячно' [1627 - SUM XVI-XVII, IV, s. 20], 'содрогательно, ужасно' [1621 - Тимченко, 2002, I, s. 97] - 'drżenie ciała' > 'strach'. вигоровута - b.o. ${ }^{10} \mathrm{SJPR}$, вигоровути - b.o. SJPR Por.: выгоровати 'возвыситься, поднесться' [Головацький, 1982, s. 438]; dial. горувати 'підноситися вгору; брати верх над ким-небудь' [ESUM I, s. 562].

\footnotetext{
${ }^{9}$ Kwalifikator boj. pochodzi od I. Wahylewycza i oznacza słownictwo bojkowskie.

${ }^{10}$ Skrót b.o. oznacza, że I. Wahylewycz nie odnotował obcojęzycznych ekwiwalentów.
} 
видаховати се - wystroić się; auszieren sich. SJPR, вилахований - b.o. SJPR (= видахований ?)

Zapewne powiązane z rzeczownikiem дaxa, por.: „даха 'род короткой шубы шерстю наружу, с капюшоном и широкими рукавами, которые не надевались "” [Грінченко, 1996-1997, I, s. 359-60]. Hasło ilustrowane utworem rymowanym, który daje świadectwo temu, że była to odzież godna książąt i panów, por.: „Одяг плечі не в жупан, не в жупан, надів даху, став як пан, став як пан”.

Według ESUM [II, s. 116] zarówno daxa, jak i wariant fonetyczny doxa 'вид кожуха з хутряним верхом' to pożyczka z języków mongolskich (por. też Фасмер, 1986-1987, I, s. 485].

виленути - b.o. SJPR

Por.: вылинути 'вылететь' [Головацький, 1982, s. 447]; вилинути поет. 'вилетіти; легко і швидко вибігти; плавно рухаючись, з’явитися, показатися' [WTSSUM, s. 99].

вирстин - b.o. SJPR

Być może należy łączyć z huc. wyrsta: wirsta 'wychrzta' [J], вирста // вирстюк 'вихрест' [HН, s. 37], zakarp. вурста 'ts.' [Чучка, 2005, s. 128], mającymi związek z ukr. вихрест, вихрист 'той, хто перейшов у християнство з іншої релігії' [WTSSUM, s. 119]. Por. z notowanymi przez Wahylewycza formami: вийрста - wychrzta, ein Austäufer; вийрстити - wychrzcić, austaufen; вийpщений, a także ръстити, ирстити, йрстити 'chrzcić'.

вистовка (IP), вистовки (IL)* - mohrige Erdhaufen; uliginosi cumuli. IL, IP Niejasne. Formalnie zbliżone do ukr. dial. вистілка 'прокладка під устілку', вустілка 'устілка (шкіряна, у селян також із соломи)' [ESUM V, s. 296-297], pol. wyściełka, wyścitka 'wysłanie, wyściełanie', wyściótka 'to, czym wysłano' [SW VII, s. 1067], chociaż dość odległe semantycznie.

витити - verbithen; vetare $^{11}$. SJPR

Identyczne co do formy buk. витити 'бути більш показним, обганяти ростом' [SBH, s. 51], odbiega od notowanej przez I. Wahylewycza formy znaczeniowo.

Por.: słc. kniž. zastar. vetit' 'hovorit', vraviet" [Králik, 2015, s. 656]. Najpewniej ma związek z ps. *větiti 'mówić'. W rękopisie autor wykreślił polski odpowiednik wzbraniać, ekwiwalent niemiecki i łaciński wskazują na znaczenie 'zabraniać'.

${ }^{11}$ Pierwotnie błędnie został odczytany z rękopisu odpowiednik łaciński (jest velare, powinno być vetare). 
вить - b.o. SJPR; вить (węg. $)^{12}(\mathrm{IL})$, (łem. $)^{13}$ (IP) - (вьть); gar; perquam. IL, IP Niejasne.

відрога - b.o. SJPR

Znane w ogólnym języku ukraińskim, jednak rzadkie, por.: відрога рідко 'те саме, що віднога' [WTSSUM, s. 138]; віднога 1. 'відгалуження гори'; 2. розм. ‘відгалуження стовбура дерева, дороги, ріки тощо’ [tamże, s. 134].

воропъ + - Zerstörung; vastatio. IL, IP

Maks Vasmer [Фасмер, 1986-1987, I, s. 354]: воропъ, др.-русск. воропъ, наворопь 'налет, нападение, ограбление' (Лаврентьевск., Ипатьевск. летоп.). Z ps. *vогрь 'напад’ [ESUM I, s. 428; ESBM II, s. 59].

воропь +- (harc); frum. andena, frum. Herb. IP

Niejasne.

вороска (huc.) - Wiege; cunnae. IL, IP

Por.: вороска 2. 'одна 3 двох мотузок або один з двох ланцюгів, на яких висить колиска' [Онишкевич, 1984, I, s. 145]; worozka 'powrózek, sznurek, na którym wisi kołyska' [Janów, 2001, s. 262].

Według ESUM [I, s. 427]: [вороза] 'мотуз, мотузок, шнурок', [ворозка] 'вервечка' Ме [...];- псл. *vorzъ, *vorza 'мотуз, вірьовка'. Tak więc nie chodzi o kołyskę, ale sznurek, na którym wisi kołyska lub nazwa została przeniesiona z uchwytu na zawieszony na nim przedmiot; por.: вороска 1. 'один з двох брусків, до яких прибита висяча колиска'; 3. 'ручка бідона' [Онишкевич, 1984, I, s. 145].

ворутка - rurka; eine Rohre; nalis. SJPR; ворутка (bojk.) (IP) - Wasserrinne; collicia. IL, IP

Niejasne. Z dużą ostrożnością można by postulować źródło turkijskie, takie samo, jakie ESUM [I, s. 304] proponuje dla бурулька 'висячий кусок льоду' (w gwarach między innymi także 'трубка, дудочка, шматочок різаної соломи'), czyli бору (boru) 'труба'. Ale to wielce wattpliwe.

U Łemków drewniana rynna do spływu gnojówki w stajni nazywa się бopmниия, буртниия [Горощак, 2004, s 26], co należy wiązać z ukr. борть 'вулик у дереві, dial. дупло', dial. борт 'тс.; паз, жолоб', борта 'трухляве всередині дерево', бортниия 'видовбаний кусок, обрубок дерева' itp., a to z ps. *bъrtb dial. płn. 'dziupla, dziura wydrążona w żywym drzewie z gniazdem pszczół;

\footnotetext{
${ }^{12}$ Kwalifikator węg. pochodzi od I. Wahylewycza i oznacza słownictwo zakarpackie.

${ }^{13}$ Kwalifikator łem. pochodzi od I. Wahylewycza i oznacza słownictwo łemkowskie.
} 
drzewo z dziuplą dla pszczół' [ESUM I, s. 235-236; SP I, s. 423]. Może więc ворутка należy do wskazanego gniazda etymologicznego, chodzi tu bowiem o drewniana rynnę, czyli inaczej wydrążony kawałek drewna.

воръ - Wagen. IL, IP

Zapewne jest to ukr. dial. вip, вор 'жеребець' [ESUM I, s. 402], a więc nie chodzi o wóz, tylko o konia. Obok hasła w rękopisie Idyotykonu Wahylewycz postawił pytajnik - może to świadczyć o tym, że sam miał wątpliwości co do tego znaczenia. W SJPR odnotował także formy op i вips z niemieckim odpowiednikiem ein Rosz 'koń'. Nie można jednak całkowicie wykluczyć przeniesienia znaczenia ze zwierzęcia pociągowego na środek transportu (mówiło się kiedyś konie czekają, mając na myśli zaprzęg, karetę itp.).

востелин - b.o. SJPR

Niejasne.

вурвуль (woł.) - Pustel; postula. IP

Poświadczone jeszcze w XVII wieku jako imię własne, por. SUM XVI-XVII [IV, s. 230]: „ворволь, ворвуль. Діал. Ворвіль 'пухир на шкірі'. Вл.н. Ярема Во(р)ву(л) (1649 Р3В 175); Федо(р) Ворво(л) (Там же, 180 зв.)”.

ESUM [I, s. 425] uznaje ukr. dial. ворвіль za wyraz niejasny i łączy z brus. dial. варволь, pol. dial. warwol [zob. SW VII, s. 469] w znaczeniu 'tran rybi' (ukr. dial. ворвань, znane też w ros. i brus.), por. także ворволь 'delphinus, meerschwein' [LSR, s. 160], brus. dial. ворвылль, ворволь 'ворвань' [ESBM II, s. 196].

O ile zbieżność formalna wskazanych powyżej wyrazów nie budzi jakichś zasadniczych wątpliwości, to zmiana znaczeniowa 'tran rybi' > 'pęcherzyk na ciele, pryszcz' już tak. ESUM proponuje jako ogniwo pośrednie znaczenie 'гнійник = ropień, wrzód', co wydaje się dość wątpliwe. Tak więc rozsądnym posunięciem będzie z pewnością traktowanie obu wyrazów jako niezależnych od siebie. Dla znaczenia 'pęcherzyk, pryszcz' odpowiednie byłoby raczej jako źródło litewskie bur̈bulas 'pęcherzyk', por.: brus. бурбалка, бурболка 'пузыр, баўдур на вадзе', ros. dial. бурболка, бурбылка, pol. burbulka, burbułka [ESBM I, s. 414; SW I, s. 235].

выгра - Stutte; equa (IP). IL, IP

die Stute 'kobyła, klacz'

Por.: выгра 'резвая, буйная кобыла', мн. ч. выгры 'неумеренное резвение' [Головацький, 1982, s. 439]. 
Prawdopodobny wydaje się związek z czasownikiem вигравати 'гарцовать': „Вигравали наші хлопці вороними кіньми” [Грінченко, 1996-1997, I, s. 154]; вигравати 'гарцювати на коні' [WTSSUM, s. 91]. Zastanawiające jednak jest to, że nazwa dotyczy tylko samicy, a nie konia w ogóle.

Być może pochodzenia tej formy należałoby szukać w nazwie niekastrowanego samca konia, por.: діал. вогир, вогір, огір 'жеребець' [Шило, 2008, s. 78]; огир 't.s.' [ESUM IV, s. 152]; brus. вогер, вогір 'жарабец' [ESBM II, s. 178]; pol. ogier, reg. ogr. Zachowanie rączej narowistej klaczy (a tak u Hołowackiego!) mogło kojarzyć się z temperamentem ogiera. Niewykluczone, że doszło tu do kontaminacji form вогир і вигравати.

выжка - Lende, Boden; lumbus, pavimentum. IL, IP

Kluczowe znaczenia mają w tym przypadku dane ze słownika Hołowackiego, por.: выљжка / вышка 1. 'подвышеное место'; 2. 'подволока, чердак'; 3. 'подмышка' [Головацький, 1982, s. 464]. Mamy tu więc oba znaczenia wskazane przez Wahylewycza, czyli 'ubita ziemia, miejsce podwyższone' oraz 'część ciała'.

Co do etymologii zob. ESUM [I, s. 382-83]: вись.

вымытка* - Karfunkel (IP), Pestbeule (IL); carbunculus. IL, IP Nazwa choroby, w pol. zwana waglikiem (także antraks, karbunkut), czyli ropne zapalenie skóry, czyraki [SW VII, s. 478].

Raczej mało prawdopodobne, aby miało to coś wspólnego z ukr. dial. вимітка 'привид, що нібито, примушує носити себе від села до села', co ESUM [III, s. 448] zamieszcza pod hasłem метати 'кидати, викидати'. Wszakże zależność od wymienionego czasownika jest jak najbardziej na miejscu, analogicznie do pol. wyrzuty 'krosty, pryszcze' [SJP III, s. 844].

W zabytkach piśmiennictwa zakarpackiego XVII-XVIII wieku spotykamy zapis выльтка w znaczeniu 'чума' [Дэжё, 1996, s. 20].

выостягати (IL), выостягати (IP) - durchprügeln; fustigare. IL, IP Por.: виостигати 'відлупцювати' [Онишкевич, 1984, I, s. 104].

Niewątpliwie pokrewne z ros. cmezamb 'chłostać, smagać', стегаться 'chłostać się, smagać się', zgodnie z sugestią redaktorów słownika gwar bojkowskich. Por. także ros. остегивать, остегать, остегнуть 'охлестывать, остегивать плетью, прутом, хворостиной’ [Даль, 1981-1982, II, s. 703].

Etymologicznie nawiązuje do ps. pierwiastka *steg-/*stog- 'bić; kłuć' [Фacмep, 1986-1987, III, s. 751; ESUM II, s. 240; III, s. 405]. 
върутнъ** - (wierutnie); sicher; certe. IP

Uznaje się za polonizm w ukr., por.: върутный (cmn. wierutny, wierudny) 'справжній, явний’ [1616] [SUM VI, s. 157]:]. ESUM [I, s. 402] cytuje także dial. вірутний 'дійсний, справжній', вірутник 'вірник'. Podobnie jako polonizm traktuje się brus. daw. верутный, вирутный 'заўзяты, страшенны' [XVII Булыка, 1972, s. 60-61], dial. вярутны 'сапраўдны' [ESBM II, s. 311].

Co do pochodzenia pol. wierutny wypowiedział się tylko Aleksander Brückner, który pisze:

wierutny, w 16. wieku (np. u Mączyńskiego) stale wirudny, 'prawdziwy, skończony' (np. łotr); jak sławętny, majętny, z u zamiast ę; niby wierzacy, ale w pierwotnem znaczeniu, t.j. 'ten, któremu się wierzy' (por. ,wierzacy list”, zawsze tak w 15. i 16. wieku, dziś wierzytel$n y)$, np. w psałterzu: „świadectwa wierzaca”' tłumaczy łac. 'credibilia', 'którym się wierzy' (tak samo giacy, 'co się da giąć', rzekacy, 'co się zowie', itp.)” [Brückner, 1985, s. 617].

A. Brückner nie podaje przyczyn zastapienia [e] przez [u], czyli zamiany jakiegoś *wierętny $(<*$ věr-ot-) na wierutny. Być może należy upatrywać tu wpływu czeskiego, por.: pol. stawetny (< stawętny), czes. slovutný 1. 'sławny, głośny, znany'; 2. 'wielmożny, zacny' [SCP, s. 719], co z ps. *slov-ot-- [Machek, 1968, s. 557]. Por. też czes. věru 'naprawdę, rzeczywiście' [tamże, s. 872], słc. veru, poet. ver', expr. veruže 'dotvrdzuje platnost'výpovede, naozaj, skutočne' [KSSJ, s. 495], niewątpliwie powiązane z viera, verit' [Králik, 2015, s. 655].

въстованс - opatrzność (SJPR 2); das Vorsehung (SJPR 1), die Vorsehung (SJRP 2); providentia. SJPR; въстований - b.o. SJPR; въстовати - opiekować. SJPR; (opiekować); sorgen; providere. IL, IP

Por.: въстованье 'попечение, провидение, промысл', въстовати 'ведать', въстоватися (-сє) 'призирать, покровительствовать' [Головацький, 1982, s. 466-467]; вістованя [Ваг. 53] 'передбачення' [Онишкевич, 1984, I, s. 131].

ESUM [I, s. 405] uznaje dial. ukr. вістуватися 'опікуватися ким, піклуватися ким' za niejasne, jednocześnie dopuszczając związek z провiдувати, навіщุати, со oznacza sprowadzenie wyrazu do ps. pierwiastka *věd- 'wiedzieć'.

Wygląda na specyficzny rozwój znaczeniowy strus. въстовати 1. 'говорить, владеть языком'; 2. 'разговаривать, беседовать'; 3. 'возвещать, сообщать'; въствовати 'проповедовать, возвещать, провозглашать что-л., говорить' [SRJ II, s. 118; 116]. 


\section{ROZWIĄZANIA SKRÓTÓW}

ESBM - МАртынАў Віктар, рэд., 1978-, Этыммалагічны слоўнік беларускай мовы, Навука і тэхніка, Мінск.

ESUM - Мельничук Олександр та ін., ред., 1982-2012, Етимологічний словник української мови, т. 1-6, Наукова думка, Київ.

HН - ЗАКревсьКА Ярослава, ред., 1997, Гуиульські говірки. Короткий словник, Інститут українознавства ім. Івана Крип'якевича НАН України, Львів.

IL - ВАгилевич Іван, Idyotykon, Oddział rękopisów Biblioteki UAN im. W. Stefanyka we Lwowie, sygn. Ваг. 55. п. 16, rejestr opublikowany we wspomnianej książce A. Budziak, s. 113-410.

IP - В - Вгилевич Іван, Idyotykon, Oddział rękopisów Biblioteki RAN w Petersburgu, sygn. coбp. А.С. Петрушевича, № 22-23, rejestr opublikowany we wspomnianej książce A. Budziak, s. 113-410.

KSSJ - KaČAla Ján, PISÁrČIKOvÁ Mária, red., 1989, Krátky slovník slovenského jazyka, Veda, Bratislava.

LSR - Lexicon slavo-ruthenicum, 2013, edycja i wstęp Adam Fałowski, scriptum, Kraków.

SBH - ГуйвАнюк Ніна, ред., 2005, Словник буковинських говірок, Рута, Чернівці.

SCP - Siatkowski Janusz, Basaj Mieczysław, 2010, Stownik czesko-polski, Wiedza Powszechna, Warszawa.

SJPR - ВАгилевич Іван, Stownik języka południowo-ruskiego, Oddział rękopisów Biblioteki RAN w Petersburgu, sygn. coбp. A.С. Петрушевича, № 22-23, rejestr opublikowany we wspomnianej książce A. Budziak, s. 113-410.

SP - SŁAWSKI Franciszek, red., 1974-, Stownik prasłowiański, t. I-VIII, Ossolineum, Wrocław.

SRJ - БАРХУдАРОв Степан, ред., 1975, Словарь русского языка XI-XVII вв., вып. I, Наука, Москва.

SUM - Гринчишин Дмитро, ред., 1994-, Словник української мови

XVI-XVII XVI - першої половини XVII cm., Інститут українознавства ім. Івана Крип'якевича НАН України, Львів.

SW - KarŁowicz Jan, KRYŃski Adam, NiedźwiedzKi Władysław, red., 1900-1927, Slownik języka polskiego, t. I-VIII, Wydawnictwo Kasy im. Mianowskiego Instytutu Popierania Nauki, Warszawa. 
WSRP - Mirska-Lasota Halina, PorawsKa Joanna, 2009, Wielki stownik rumuńsko-polski, Wydawnictwo Uniwersytetu Jagiellońskiego, Kraków.

WTSSUM - Бусел В'ячеслав, ред., 2001, Великий тлумачний словник сучасної украӥнської мови, Перун, Київ-Ірпінь.

\section{BIBLIOGRAFIA}

Boryś Wiesław, 2008, Słownik etymologiczny języka polskiego, Wydawnictwo Literackie, Kraków.

BRÜCKNER Aleksander, 1985, Słownik etymologiczny języka polskiego, Wiedza Powszechna, Warszawa.

BudziaK Anna, 2014, Rękopiśmienna spuścizna słownikarska Iwana Wahylewycza, seria „Studia Ruthenica Cracoviensia” 8, Scriptum, Kraków.

Buffa Ferdinand, 2004, Slovník šarišských nárečí, Náuka, Prešov.

Doroszewski Witold, 1958-1969, Stownik języka polskiego, https://sjp.pwn.pl/ doroszewski/ (dostęp: 20.11.2017).

FaŁowski Adam, Budziak Anna, 2018, Stownictwo ukraińskie ze zbiorów I. Wahylewycza (1), „Studia Ucrainica Varsoviensia”, 6, s. 45-59.

JANów Jan, 2001, Stownik huculski, opracował i przygotował do druku Janusz Rieger, Wydawnictwo Naukowe DWN, Kraków.

JURKOWSKI Marian, 1971, Ukraińska terminologia hydrograficzna, seria „Monografie Slawistyczne Komitetu Słowianoznawstwa PAN 22”, Zakład Narodowy im. Ossolińskich, Wrocław-Warszawa-Kraków-Gdańsk.

Kálal Karel, Kálal Miroslav, 1923, Slovenský slovnik z literatury aj nárečí, Slovenská Grafia, Banská Bystrica.

KRÁLIK L'ubor, 2015, Stručný etymologický slovnik slovenčiny, Jazykovedný ústav L’udovíta Štúra SAV, Bratislava.

MACHEK Václav, 1968, Etymologický slovník jazyka českého a slovenského, Academia, Praha.

SADNIK Linda, AItZETMÜLLER Rudolf, 1989, Handwörterbuch zu den altkirchenslavischen Texten, Universitätsverlag Winter, Heidelberg.

Аникин Александр, 2012, Русский этимологический словарь, т. 6, Институт русского языка РАН, Москва.

БулыкА Аляксандр, 1972, Даўнія запазычанні беларускай мовы, Навука і Тэхніка, Мінск. 
ВЕРХРАтсьКий Іван, 1902, Про говор галиџких Лемків, „Збірник Філологічної секції НТШ”, V, Львів.

ГоловацьКий Яків, 1982, Словник української мови, опублікували Йосип Дзендзелівський, Зузана Ганудель, Науковий збірник МУК у Свиднику, т. 10, с. 311-362, Пряшів.

ГорьАч Олекса, 1997, Південнобуковинська говірка села Милешовеиь бл. Радовець (Румунія), в: О. Горбач, Зібрані статті VIII. Історія мови. Діалектологія. Лексикологія, Український Вільний Університет, Мюнхен. ГорощАк Ярослав, 2004, Словник лемківсько-польскій польско-лемківскій, Rutenika, Warszawa.

Грінченко Борис, ред., 1996-1997, Словарь української мови, т. I-IV, Наукова думка, Київ.

Даль Владимир, 1981-1982, Толковый словарь живаго великорусского языка, т. I-IV, Русский язык, Москва.

ДэжЁ Ласло, 1996, Деловая письменность русинов в XVII-XVIII веках. Словарь, анализ, тексты, под общей редакиией Иитвана Удвари, Studia Ukrainica et Rusinica. Nyíregyháziensia 4, Nyíregyháza.

Онишкевич Михайло, 1984, Словник бойківських говірок, т. I-II, Наукова думка, Київ.

Тимченко Євген, 2002, Матеріали до словника писемної та книжної украӥнської мови $X V-X V I I I$ cm., т. I-II, Інститут української мови НАН України, Київ.

ФАСмеР Макс, 1986-1987, Этимологический словарь русского языка, т. I-IV, Прогресс, Москва.

Черниш Тетяна, 2003, Слов'янська лексика в історико-етимологічному висвітленні, Інститут філології Київського національного університету ім. Т. Шевченка, Київ.

ЧЕрных Павел, 2001, Историко-этимологический словарь современного русского языка, т. I-II, Русский язык, Москва.

ЧучкА Павло, 2005, Прізвища закарпатських украӥнців. Історико-етимологічний словник, Світ, Львів.

ШАнский Николай М., 1963-, Этимологический словарь русского языка, т. I, вып. 1, Издательство Московского университета, Москва.

Шило Гаврило, 2008, Наддністрянський регіональний словник, Інститут українознавства ім. Івана Крип'якевича НАН України, Львів. 


\section{Adam Fałowski, Anna Budziak}

\section{SŁOWNICTWO UKRAIŃSKIE ZE ZBIORÓW IWANA WAHYLEWYCZA (2)}

\section{Streszczenie}

Artykuł kontynuuje serię publikacji, w których autorzy przedstawiają rzadkie, dialektalne, niekiedy archaiczne jednostki leksykalne wyekscerpowane $\mathrm{z}$ niedawno uporządkowanych i wydanych drukiem słowników ułożonych przez Iwana Wahylewycza. W dwóch wariantach Idyotykonu i w Słowniku języka południowo-ruskiego udało się wyszukać około 700 leksemów, które albo zostały pominięte w słowniku etymologicznym języka ukraińskiego, albo wymagają szerszego komentarza leksykologicznego. W niniejszej publikacji omówiono 36 wyrazów, które zaczynają się na literę W.

\section{UKRAINIAN VOCABULARY FROM IVAN VAHYLEVYCH'S COLLECTION (2) Summary}

The article continues a series of publications, in which the authors present rare, dialectical, sometimes archaic lexical units extracted from the recently published dictionaries by Ivan Vahylevych. In two variants of Idyotykon and in the Dictionary of the South-Ruthenian Language they managed to reveal about 700 lexical items, which were either omitted from the Etymological Dictionary of the Ukrainian Language, or required more detailed lexicological commentary. 36 words starting with $\mathrm{W}$ are discussed in the article. 